\title{
ФОРМИРОВАНИЕ ЛИЧНОСТНЫХ УНИВЕРСАЛЬНЫХ УЧЕБНЫХ ДЕЙСТВИЙ У МЛАДШИХ ШКОЛЬНИКОВ (НА ПРИМЕРЕ НРАВСТВЕННО-ЭТИЧЕСКОЙ ОРИЕНТАЦИИ)
}

\section{Лаптиева Г.Г.}

Федеральное государственное бюджетное

образовательного учреждение высшего образования «Воронежский государственный педагогический университет», г. Воронеж, Российская Федерация

Одним из компонентов личностных универсальньхх учебных действий является нравственно-этическая ориентация. В статье представлены критерии и уровни сформированности нравственноэтической ориентации у младших школьников

Ключевые слова: личностные универсальные учебные действия; нравственно-этическая ориентация; уровни сформированности нравственно-этической ориентации.

\section{FORMATION OF PERSONAL COMMON TRAINING ACTIVITIES IN JUNIOR SCHOOLCHILDREN (BASED ON MORAL-ETHICAL ORIENTATION)}

\author{
Laptieva G.G. \\ Voronezh State Pedagogical University, \\ Voronezh, Russian Federation
}

Moral-ethical orientation is one of the components of personal common training activities. The paper examines the types of moral-ethical orientation, its criteria and level of its formation in junior schoolchildren.

Keywords: personal common training activities; moral-ethical orientation; level moral-ethical orientation formation. 
Характерная особенность современной системы начального общего образования - нацеленность на формирование у обучающихся начального звена школы универсальных учебных действий, обеспечивающих способность младших школьников в будущем самостоятельно работать над собой, саморазвиваться.

В Фундаментальном ядре содержания общего образования [3] одной из четырех групп универсальных учебных действий являются личностные универсальные действия. Внутри них, в свою очередь, выделяются следующие компоненты: личностное, профессиональное и жизненное самоопределение, действие саморазвития и нравственно-этической ориентации. В основе этих компонентов заложены важнейшие качества полноценного развития - осознание младших школьником необходимости учиться; проявление интереса к новым знаниям, стремление к достижению высокого уровня знаний и их оценке; формирование учебной мотивации; безошибочное представление о моральных нормах и т.д.

Под нравственно-этической ориентацией понимается «выбор действия в условиях морального конфликта», включающий в себя выделение морального содержания поступка и его мотива, а также опознавание и осознание моральных чувств.

Действия нравственно-этической ориентации и основные критерии её оценивания выделены А.Г. Асмоловым [1]:

1. Выделение морального содержания ситуации: отступление от моральной нормы или следование ей.

2. Различение моральных и конвенциональных (общепринятых) норм - ребенок понимает, что нарушение моральных норм оценивается как нечто неприемлемое, по сравнению с нормами общепринятыми.

3. Осуществление морального выбора при достаточном уровне моральной зрелости, когда ребенок способен оценить объективные последствия нарушения нормы; учесть мотивы субъекта, нарушившего норму, его чувства и эмоции; принять решение на основе сопоставления нескольких моральных норм.

4. Адекватность оценки действий субъекта с позиции соблюдения или нарушения моральной нормы. 
5. Достаточный уровень развития моральных суждений, позволяющий правильно обосновывать необходимость выполнения моральной нормы.

Ниже представлены уровни сформированности нравственноэтической ориентации у младших школьников.

\section{Высокий уровень}

У ребенка ярко выражена постоянная ориентация на моральные нормы, мотивы, обстоятельства поступка, намерения, эмоции и чувства субъекта, четкое выделение морального содержания, выполнения нормы взаимопомощи, активное принятие установки на просоциальное поведение (приносящее пользу другим людям). Наблюдается высокий уровень проявления децентрации как способности к соотнесению норм справедливого распределения, ответственности, взаимопомощи на основе принципа компенсации (когда выигравший способен восполнить потери проигравших). Присутствует устойчивое понимание того, что нарушение моральных норм влечет за собой серьезные объективные последствия. Необходимое решение принимается им на основе соотнесения нескольких моральных норм. Ребенок способен адекватно оценить действия с точки зрения соблюдения моральной нормы, ориентации на интересы других людей, нуждающихся в помощи. Для него характерен высокий (конвенциональный) уровень моральных суждений - так называемая «стадия «закона и порядка»»» - люди должны помогать друг другу, оказывать взаимопомощь».

\section{Средний уровень}

У младшего школьника недостаточно ярко выражена ориентация на моральные нормы, выделение морального содержания ситуации несколько размыто. Он учитывает нормы взаимопомощи как основания построения межличностных отношений, но норма справедливого распределения действий выражена недостаточно. Наблюдается неустойчивая ориентация на просоциальное поведение, на мотивы поступка и правдивости моральных суждений, но 
яркая выраженность на обстоятельства и объективные последствия поступка. Ребенок нерационально соотносит нормы справедливого распределения, но наблюдается переход к координации нескольких норм. Хорошо развиты моральные суждения при наблюдении нарушения моральных норм, однако при этом не всегда учитываются эмоции и чувства субъекта, решение принимается спонтанно. Оценка моральных действий субъекта происходит на основе собственных интересов с учетом интересов других людей. Развитие моральных суждений находится на стадии «межличностной комфортности и сохранения хороших отношений - друзьям необходимо помогать».

\section{Низкий уровень}

У ребенка отсутствует ориентация на моральную норму, выделение морального содержания поступка, но сохраняется ориентация на эмоции и чувства субъекта. Отсутствует установка на просоциальное поведение, оценка поведения неадекватна. Школьник не может выделить моральное содержание ситуации, не знает сути нравственных норм, которые, как следствие, не являются мотивами его поведения; осуществляет учет только одной нормы (справедливого распределения), не учитывая всех обстоятельств, в том числе намерений субъекта. Отсутствует ориентация на обстоятельства поступка, интересы и потребности других людей. Ярко выражена направленность личности только на себя, решение проблемы происходит в пользу собственных интересов, хотя и с оглядкой на мнение окружающих. Развитие моральных суждений находится на стадии «инструментального обмена - сначала ты поможешь мне, а потом я тебе».

Для выявления уровней сформированности нравственно-этической ориентации у младших школьников можно использовать, в частности, методики Ж. Пиаже: «Задание на оценку усвоения нормы взаимопомощи», «Задание на учет мотивов героев в решении моральной дилеммы», «Задание на выявление уровня моральной децентрации»; «Моральная дилемма (норма взаимопомощи в конфликте с личными интересами) ». 
Полагаем, что основными путями формирования нравственноэтической ориентации (как личностного универсального действия) у младших школьников являются следующие:

1. Содержание образования в целом и, в частности, формирование нравственно-этических ориентаций у младших школьников должно ориентироваться на систему значимых для присвоения младшими школьниками (построенных с учетом их возрастных особенностей и задач современной начальной школы) базисных ценностей - гуманное отношение друг к другу, толерантность, готовность к сотрудничеству и дружбе, взаимное уважение между людьми, товарищеская взаимопомощь и требовательность, чувство прекрасного, коллективизм, воспитание заботы о старших и младших в семье.

2. В систему урочных и внеурочных занятий необходимо включать задания/упражнения, формирующие вышеперечисленные ценности и востребующие умения:

- самопознания ребенком собственных внутренних состояний, переживаний в процессе взаимодействия с «другими» и в ходе последующей их оценки,

- определения своей моральной позиции в различных жизненных ситуациях, в том числе нравственного выбора,

- самостоятельного принятия решений, познания других людей, анализа и оценки нравственной стороны их поступков;

- осуществления личностного морального выбора, оценивания событий и действий с точки зрения моральной нормы, понимания и учета объективных последствий нарушения моральной нормы.

3. Изучение моральных норм в деятельностной форме (помощь нуждающимся, слабым и беззащитным, забота о природе, животных и т.д.), привлечение детей к участию в общественнополезной деятельности (волонтерство, шефская помощь и др.) для реализации норм взаимопомощи и ответственности.

4. Стимулирование личной ответственности за сказанное слово, совершенное действие, данное обещание; чувствительности и 
сопереживания к бедам других людей; создание повседневной установки в адрес детей на их доброжелательность, уважение друг к другу, добрый эмоциональный климат взаимоотношений.

\section{Список литературы}

1. Асмолов А.Г. Как проектировать универсальные учебные действия в начальной школе: от действия к мысли: пособие для учителя / А.Г. Асмолов [и др.]; под ред. А.Г. Асмолова. Москва: Просвещение, 2008. $151 \mathrm{c}$

2. Оценка достижения планируемых результатов в начальной школе. Система заданий. В 3 ч. / Л.Л. Алексеева [и др.]; под ред. Г.С. Ковалёвой, О.Б. Логиновой. Москва: Просвещение, 2011. 240 с.

3. Фундаментальное ядро содержания общего образования / Под ред. В.В. Козлова, А.М. Кондакова. Москва: Просвещение, 2009. 48 с.

\section{References}

1. Asmolov A.G. Kak proektirovat' universal'nye uchebnye deystviya v nachal'noy shkole: ot deystviya k mysli: posobie dlya uchitelya / A.G. Asmolov i dr.; pod red. A.G. Asmolova. Moskva: Prosveshchenie, 2008. $151 \mathrm{~s}$.

2. Otsenka dostizheniya planiruemykh rezul'tatov $v$ nachal'noy shkole. Sistema zadaniy. V 3 ch. / L.L. Alekseeva [i dr.]; pod red. G.S. Kovalevoy, O.B. Loginovoy. Moskva: Prosveshchenie, 2011. 240 s.

3. Fundamental'noe yadro soderzhaniya obshchego obrazovaniya / Pod red. V.V. Kozlova, A.M. Kondakova. Moskva: Prosveshchenie, 2009. 48 s. 